\title{
Communication
}

\section{California's Groundwater Regime: The Cadiz Case}

\author{
Julia Sizek \\ Anthropology Department, University of California-Berkeley, Berkeley, CA, 94720, USA; jsizek@berkeley.edu
}

Received: 18 November 2017; Accepted: 18 January 2018; Published: 21 January 2018

\begin{abstract}
Recent California legislation has promised solutions to longstanding problems in groundwater management through an emphasis on management of groundwater itself, rather than on the rights of overlying property owners. In this short communication, I argue that the promises of scientific management relies on property law and jurisdiction and therefore that scientific claims about the water itself are less important than private property claims in the case of a Cadiz Inc.'s proposed groundwater extraction project in Southeastern California. While private property in land insulates Cadiz Inc. (Los Angeles, CA, USA) from political contestation, opposition to the project has increasingly focused on the right to transport and transfer water through lands not held by Cadiz Inc. This legal strategy points to how California groundwater law is still fundamentally ruled by private property in land, which shifts the grounds of environmental politics from extraction itself to the transport of extracted materials. This case serves as a good example of the intersection of political ecology and legal geography.
\end{abstract}

Keywords: legal geography; groundwater; private property; political ecology; water rights; right-of-way; scale

\section{Introduction}

California depends on groundwater: 50\% of water used in the state comes from underground stores. Despite its importance to water provision throughout the state, groundwater has remained largely invisible to the general public. As a result, groundwater-related problems such as overdraft and land subsidence plague the state [1].

The 2014 passage of the Sustainable Groundwater Management Act (SGMA) promises to solve California's recalcitrant groundwater problems by creating agencies to oversee groundwater that correspond to groundwater basins. Prior to SGMA, California's groundwater was determined on a case-by-case basis as landowners overlying the same aquifer sued each other to adjudicate their rights to extract water from the basin below [2]. The case-by-case adjudication resulted in a patchwork of legal regulation around the state, which has been hailed by some as successful instances of polycentric governance structures and disparaged by others as piecemeal policy [2,3]. The passage of SGMA ensured groundwater plans would be made for medium- and high-priority basins where adjudication had never occurred between overlying property owners.

Basin-scale management has long been the dream of California's water managers, and the idea of watershed-scale management dates back to John Wesley Powell's explorations of the American West in the mid-1800s [4,5]. Matching management scale to hydrologic scale promises to reshape groundwater management from property boundaries to scientific ones rather than the politics of overlying owners [5].

This short communication examines this central promise of SGMA - that groundwater itself can be centered in debates about proposed extraction, rather than the property rights of overlying owners. Through examining a legal contestation and public discourse around a proposed groundwater project in Southeastern California, this short communication argues that California groundwater policy is ruled by private property rights, not by scientific management practices. This fact shifts possibilities 
for legal contestation away from the project itself and toward the material infrastructure needed to complete groundwater transfer. In the first section, I describe how the Cadiz Inc. project fits into the history of California water and private property law pre-SGMA, introducing the key concepts of "reasonable use" and "surplus water" as key ways of understanding the relationship between water and property. In the second, I describe challenges to the Cadiz Inc. project in the form of scientific questions about groundwater pumping rates and their lack of success in creating meaningful debate around the project because jurisdictional issues raise the question not of whether the project should happen but rather of how much they are allowed to pump. Finally, I discuss how groundwater transport has become the primary site of contestation over the project, and the ways that this reinforces private property regimes.

\section{Background: The Cadiz Project under California Groundwater Law}

Although Cadiz Inc. has often appeared to be an agricultural company, their 1987 SEC 10-K filing indicates that the original incorporated company, Aridtech, was a "water exploration and development company" meant to acquire underground water resources. In 1985, Aridtech incorporated the Cadiz Valley Development Incorporation, and both of these organizations became the Cadiz Inc. Company known today. Over time, Cadiz Inc. has added more land, and now they have approximately 40,000 acres in the Eastern Mojave around their project area, though the land is not contiguous [6].

In 1983, the company now known as Cadiz Inc., a water and natural resources company, acquired about 14,000 acres of creosote scrub in the Eastern Mojave Desert on the assumption that the relatively closed aquifer underneath it would yield profits once the water was moved and sold [6]. Like other agricultural speculators after the 1977-1978 drought, they sought to take advantage of the property tax benefits of Proposition 13 and low land prices to invest in the land market. This investment was based on the idea that acquiring overlying land would grant rights to water that could appreciate in value [7]. Later, the groundwater could be transferred to a new owner because of 1982 laws that eased groundwater permit transfers to private and public water companies [8]. In the 1990s, the company unsuccessfully proposed a groundwater storage project (similar to the Kern Valley Water Bank), and today's iteration of the project is to extract and transport it to coastal water districts. This project is controversial, and almost universally derided by those living in the Mojave Desert, where the project is located. In more than 20 interviews I conducted in the summer and fall of 2017 with residents of the Morongo Basin, East Mojave Desert, and Barstow, most locals adhered to a similar narrative: they oppose the project as a profitable "water grab" for Cadiz Inc. that would subsidize irresponsible water use by coastal Californians to the detriment of a fragile desert ecology.

Though local opposition to the project is relatively high, the project has legal precedent in California. Since no statewide oversight for groundwater existed until 2014 [9], groundwater before that time was governed by a legal precedent known as "California correlative rights," or "reasonable use," which is distinct from the laws governing surface water in the state. California's correlative rights doctrine came from the 1903 court case Katz v. Walkinshaw, which established that overlying property owners had access to the water below and that such limits to the use of water could only be proven if they extended beyond "reasonable use" $[10,11]$. Though these water rights are still use rights rather than property rights, California's system is only one step removed from treating water as absolute private property, as in Texas [12].

"Reasonable use" creates an interesting problem in the relationship between water and land in California groundwater law: though it is primarily used as a way to limit overlying users from using too much water or wasting water, it makes possible the legal phenomenon of "surplus" water [8]. "Surplus" water is created when the overlying owners' reasonable use is determined, but that the combined amount of water needed by each user is less than the total water that can be safely extracted each year [10]. This so-called surplus water can then be appropriated and conveyed to non-overlying users through groundwater permitting schemes, largely because the California Constitution mandates beneficial use of water by humans over in-stream uses for wildlife [13]. 
For the Cadiz project, the creation of "surplus" water in the aquifer is central to their profit-making strategy. Unlike many overdrafted aquifers throughout the state shared between private landowners, the aquifer underlying the Cadiz, Fenner, and Bristol Valleys are shared largely between Cadiz Inc. and the federal government. In this area, the federal government has not sued to adjudicate the basin and seems to favor human use over in-stream uses for local flora and fauna [6,14]. As a result, all appropriable groundwater can go to Cadiz Inc. even if their use extends beyond reasonable use needed for their lands.

The California legal system has created a unique legal ecology in which projects like Cadiz can thrive by basing access to groundwater on the private rights of overlying landowners. Like mineral rights, these water rights are both connected to and alienable from the land under property law [15]. (On the limits of water-as-mineral, see Andrus v. Charlestone Stone Prods. Co., (436 U.S. 604, 1978), a Supreme Court case heard in which a man tried to file a patent under the 1872 mining act for the water underneath the land. In the decision, the Supreme Court determined that groundwater could not be patented under the act because it was neither named in the act nor under the jurisdiction of the federal government). The dual legal status of water rights also demonstrate how critical legal geography-understanding the legal underpinnings of resource extraction-intersects with the political ecology of extraction and profit [16-18]. In the following two sections, I focus on the ways that environmental organizations and others have contested the Cadiz project through tracing legal action surrounding the Cadiz project. Through following these legal questions, I argue that scientific basin-wide claims about water have been legally unsuccessful, as claims about private property in conveyance areas have had greater traction, revealing how property law rules water rights.

\section{The Contested Science of the Groundwater Basin}

Although groundwater is an extremely important component of water provision, it is known to many managers as the "unseen" or "invisible" resource because it is hidden from sight and its importance remains unrecognized by the general public [19]. While groundwater is increasingly important in providing water to consumers (especially in times of drought), much remains uncertain about the groundwater hydrology. In the Cadiz case, both Cadiz Inc. and environmentalist opposition have used this uncertainty to make claims about the effects of the project during the California Environmental Quality Act (CEQA) process. Opposition to the project has proven unsuccessful at challenging the hydrological basis and jurisdiction of the project, demonstrating how only the extent of the project can be questioned, not its validity.

Two particularly contested issues are basin connectivity and recharge rates, both of which are central to understanding the long-term effects of groundwater extraction, which include effects to local water sources, saltwater intrusion in coastal areas, and land subsidence. Aquifers are most often imagined as closed bowls containing water, an image that serves a utilitarian and political purpose in delineating communities of interest $[5,20]$. Few aquifers fulfill this ideal. Subsurface geology determines where the aquifer connects to other underground water sources (in California, this has also appeared famously in debates about connectivity between surface water and groundwater, in City of Los Angeles v. Pomeroy (1899)), or in what ways overdraft from that aquifer could affect surrounding water sources. In the case of the Cadiz project, the limits of the aquifer are hotly contested: environmental groups have claimed hydraulic connection between the Bonanza Spring, a year-round water source for desert flora and fauna, and the Fenner and Orange Blossom aquifers, though the company denies this connection. Even if such beneficial use of the water were proven, it would be unlikely to hinder the project: indirect benefits of water to wildlife are typically understood to be less important than direct beneficial use to people [14].

Calculating groundwater recharge rates is also notoriously complex, since it depends on the collection of rainwater that percolates to the aquifer (and possibly other stream or river sources). Recharge rates are also affected by discharge rates, including springs and dry lakebeds, both of which are at issue for this aquifer [20]. Though these processes are simple in concept, they are difficult to 
measure practically, and many proposed recharge rates vary widely. In the case of the Cadiz project, groundwater recharge rates range from a 2000 Maxey/Eakin study by USGS predicting 2550 to 11,200 acre-feet per year to a Cadiz-funded study in 2010 that gave a proposed recharge rate of 32,000 acre-feet per year [6,21]. (Of note: The scientific analyses for the project propose that the water transferred to SMWD would be otherwise lost to evaporation through dry lake beds, so the project "saves" water from natural inefficiencies, using the same logic of the "wastefulness" of nature outlined in Gidwani and Reddy's (2011) analysis of the simultaneously moral and economic character of languages of water use [22]). While these differences in estimates could be quite consequential, they are hard to assess when the project is enacted, since many detrimental impacts of pumping are only seen long after the pumping is completed [20].

Much of the science surrounding the Cadiz aquifer has been contested by environmental agencies and by the federal government during the CEQA process, as attested above. Because so much of CEQA is based on mitigating harms rather than eliminating them [22], these challenges have not fundamentally questioned Cadiz Inc.'s right to draw so-called "surplus" water from the basin beneath them and instead have only questioned the quantity of water available to Cadiz. The reason why these legal challenges by environmentalists have failed is not because of the invalidity of scientific questions, but because of jurisdiction and private property: California's correlative rights doctrine has insulated Cadiz Inc. from legal challenges about their right to move water beneath their land. The question as framed under CEQA, like the technical solutions under SGMA, is one of how much extraction is permissible, not whether such extraction should be allowed. As a result, the legal arena for contestation about the Cadiz project has shifted to the actual conveyance of water to SMWD through an old railroad right-of-way. This right-of-way, not the aquifer itself, has been the most fruitful site of legal contestation over the project.

\section{Pipeline Politics}

Cadiz Inc. has long planned to transfer water away from their pumping stations through a pipeline they would construct in the right-of-way on the Arizona and California railroad line that travels from Cadiz to the Colorado River aqueduct. As much as the public discourse surrounding the water transfer has generally played out along the ethics of selling and transporting water from the desert to coastal Orange County (as seen in my interviews with members of the public, newspaper articles [23], and op-eds $[24,25])$, the most concrete legal action has been about the property regimes of the transport process, and whether Cadiz Inc. should be allowed to use old railroad right-of-ways without federal review. The success of this legal strategy in opposing the project points to the underlying importance of property in land in determining the fate of the project.

Built from 1905 to 1907, the Arizona-California line of the Santa Fe railroad traveled from Cadiz (CA) to Parker (AZ), receiving a right-of-way from the federal government, as did many transcontinental railroads of the time [26]. This grant, under the 1875 railroad right-of-way act, is between an easement and an outright fee grant of the land, as had been determined by Great Northern Railway Company v. United States (1942). The status of railroad right-of-ways had always been a moot point, and was debated in myriad forms in Leo Sheep Co. v. United States (1979) and Home on the Range $v$. ATET Corporation (2005), which determined that (1) grants from the federal government are "construed strictly against the grantees" and (2) that railway right-of-way easements were limited to that of a railroad purpose following the narrow interpretation of the easement.

Under an Obama-era Department of the Interior solicitor's decision (M-37025), Cadiz Inc. would have to undergo federal review to build their pipeline on federal lands because the proposed pipe did not further a railway purpose under Home on the Range and therefore did not fall within the grant provided to the railway company, narrowly construed. This 2011 decision decided on the basis of property law that Cadiz Inc.'s conveyance pipeline would have to undergo federal review (rather than only CEQA, which had dictated the terms of their previous review). However, this decision was rescinded and replaced with M-37048 by the Trump Administration's Acting Solicitor Daniel Jorjani in 
September 2017. In this new decision, Jorjani argues against the Supreme Court's decision in Home on the Range, instead stating that railroad right-of-ways should be understood as a gross easement with divisible bundles of rights that can be sold at a profit (as in property, cf. Kay [27]). Under his guidance, the railroad maintains the right to divide up its right-of-way easement as long as the new right-of-way use does interfere with railroad activities.

As a rejoinder to the Trump Administration's efforts to have the project not receive further review, the state of California has found that it owns lands underlying the railroad right-of-way and therefore that the California State Lands Commission will have to review the proposed project conveyance for a lease. At the time of writing, decisions are not final as to what the California State Lands Commission will decide in their review process. However, what both of these cases show is how the politics of groundwater are fought not through the water itself or the right to extract, but through the land above it-in the latter case, the land through which the water must be conveyed. This points toward the ways that questions of private property in land - even outside of the area properly understood as part of the basin-come to determine groundwater politics.

What is so legally contested in the case of right-of-ways is exactly the discussion not being asked in the case of overlying ownership of groundwater: what is the degree to which a right-of-way (a form of use-right) conveys a right in property? This litigation reveals a re-working of legal scale to question the boundaries of property and rights ownership [28] and to reconfigure the ways in which property rights are important for understanding contemporary extractive projects.

\section{Conclusion: Property in Water}

Property law is both the central tool Cadiz Inc. has in protecting their groundwater extraction plans and their chief enemy as they attempt to convey the water through the desert to the Colorado River Aqueduct. The legal debates that have emerged from Cadiz Inc.'s proposed conveyance are in exact opposition to those that SGMA conceptually relies on: rather than bringing parties to the table to discuss aquifer recharge rates and the science of groundwater, the debate of the project is about a distinction between property and right-of-way. The pipeline infrastructure becomes the means of debating the entirety of the project, as in the case of debates over Keystone XL and Dakota Access pipelines $[29,30]$. Unlike these fossil fuel pipelines, Cadiz's proposed pipeline does not pose a danger to people-in fact, Cadiz Inc. has attempted to permit the pipeline as necessary for railroad fire suppression - but the underlying debate is about whether the project will harm wildlife by extracting groundwater and whether it is appropriate to remove water from the desert for profit. The debates over the right-of-way are a proxy for debates made impossible under the legal system: should water be sold for profit? Do affected wildlife have rights?

The railroad debate combines aspects of the political economy of water extraction and legal scale through revealing the private property rights that both promote water extraction and make water conveyance difficult. In this intersection, the controversial groundwater project faces its most potent opposition through the pipeline rather than through claims on the water rights of the overlying property owners themselves, much like in cases of fossil fuel industries. The politics of the groundwater project are not seen through the still-invisible aquifer, but instead through the visible pipeline that will travel through the California desert.

Acknowledgments: This research has been supported by a fellowship from the National Science Foundation's Graduate Research Fellowship Program.

Conflicts of Interest: The authors declare no conflict of interest. The funding sponsors had no role in the design of the study; in the collection, analyses, or interpretation of data; in the writing of the manuscript; or in the decision to publish the results.

\section{References}

1. Faunt, C.; Sneed, M.; Traum, J.A.; Brandt, J. Water Availability and Land Subsidence in the Central Valley, California, USA. Hydrogeol. J. 2016, 24, 275-284. [CrossRef] 
2. Blomquist, W.A. Dividing the Waters: Governing Groundwater in Southern California; ICS Press: San Francisco, CA, USA, 1992.

3. Tarlock, A.D. Putting rivers back in the landscape: The revival of watershed management in the United States. Hastings West Northwest J. Environ. Law Policy 2000, 6, 167-195.

4. Powell, J.W. Report of the Lands of the Arid Region of the United States, With a More Detailed Account of the Lands of Utah, 2nd ed.; Government Printing Office: Washington, DC, USA, 1879.

5. Blomquist, W.; Schlager, E. Political Pitfalls of Integrated Watershed Management. Soc. Nat. Resour. 2005, 18, 101-117. [CrossRef]

6. Santa Margarita Water District. Cadiz Valley Water Conservation, Recovery, and Storage Project; Final Environmental Impact Report; SCH\# 2011031002; Santa Margarita Water District: Rancho Santa Margarita, CA, USA, 2012.

7. Gaffney, M. What Price Water Marketing?: California's New Frontier. Am. J. Econ. Sociol. 1997, 56, 475-520. [CrossRef]

8. Gray, B.E. A Primer in California Water Transfer Law. Ariz. Law Rev. 1989, 31, 745-781.

9. Escriva-Bou, A.; McCann, H.; Hanak, E.; Lund, J.; Gray, B. Accounting for California's Water; Public Policy Institute of California: San Francisco, CA, USA, 2016.

10. Brown, J.A. Uncertainty Below: A Deeper Look into California Groundwater Law. Environ. Law Policy J. 2015, 39, 45-95.

11. Sax, J.L. We Don't Do Groundwater: A Morsel of California Legal History. Univ. Denver Water Law Rev. 2003, 6, 270-317.

12. Gardner, R.; Moore, M.R.; Walker, J.M. Governing a Groundwater Commons: A Strategic and Laboratory Analysis of Western Water Law. Econ. Inq. 1997, 35, 218-234. [CrossRef]

13. Cantor, A. Material, Political, and Biopolitical Dimensions of 'Waste' in California Water Law. Antipode 2017, 49, 1204-1222. [CrossRef]

14. Losi, C.J. Keeping Dry Streams Green: Can Landowners in Arizona and California Use Property Rights to Maintain Groundwater-Dependent Riparian Habitat Along Non-Perennial Watercourses. Hastings West Northwest J. Environ. Law Policy 2012, 18, 121-156.

15. Blomley, N. Law, Property, and the Geography of Violence: The Frontier, the Survey, and the Grid. Ann. Assoc. Am. Geogr. 2003, 93, 121-141. [CrossRef]

16. Andrews, E.; McCarthy, J. Scale, Shale, and the State: Political Ecologies and Legal Geographies of Shale Gas Development in Pennsylvania. J. Environ. Stud. Sci. 2014, 4, 7-16. [CrossRef]

17. Bebbington, A. Underground Political Ecologies: The Second Annual Lecture of the Cultural and Political Ecology Specialty Group of the Association of American Geographers. Geoforum 2012, 43, 1152-1162. [CrossRef]

18. Huber, M.T.; Emel, J. Fixed Minerals, Scalar Politics: The Weight of Scale in Conflicts over the ' 1872 Mining Law' in the United States. Environ. Plan. A 2009, 41, 371-388. [CrossRef]

19. Blomquist, W.; Ingram, H.M. Boundaries Seen and Unseen. Water Int. 2003, 28, 162-169. [CrossRef]

20. Heath, R.C. Basic Ground-Water Hydrology; U.S. Geological Survey: Reston, VA, USA, 1983.

21. Dubois, S.R. Re: National Park Service Comments to Draft Environmental Impact Report for the Cadiz Valley Water Conservation, Recovery and Storage Project; United States Department of the Interior: Washington, DC, USA, 2012.

22. Gidwani, V.; Reddy, R.N. The Afterlives of 'Waste': Notes from India for a Minor History of Capitalist Surplus. Antipode 2011, 43, 1625-1658. [CrossRef]

23. Aron, H. A Controversial Plan to Drain Water from the Desert? Go for It, Trump Administration Says; L.A. Weekly: Culver City, CA, USA, 2017.

24. Feinstein, D.; Friedman, L. The Scheme to Pump Desert Water to L.A. Could Destroy the Mojave. California's Legislature Needs to Block It; Los Angeles Times: Los Angeles, CA, USA, 2017.

25. Castro, L. Protect the Groundwater beneath Our National Treasures; SCV: Santa Clarita, CA, USA, 2017.

26. Myrick, D.F. Railroads of Nevada and Eastern California; Howell-North Books: Berkeley, CA, USA, 1963.

27. Kay, K. Breaking the Bundle of Rights: Conservation Easements and the Legal Geographies of Individuating Nature. Environ. Plan. A 2016, 48, 504-522. [CrossRef]

28. Jepson, W. Claiming Space, Claiming Water: Contested Legal Geographies of Water in South Texas. Ann. Assoc. Am. Geogr. 2012, 102, 614-631. [CrossRef] 
29. Barry, A. Material Politics: Disputes along the Pipeline; Wiley: Oxford, UK, 2013.

30. Bond, D. The Promising Predicament of the Keystone XL Pipeline. Anthropol. Now 2015, 7, 20-28. [CrossRef]

(C) 2018 by the author. Licensee MDPI, Basel, Switzerland. This article is an open access article distributed under the terms and conditions of the Creative Commons Attribution (CC BY) license (http://creativecommons.org/licenses/by/4.0/). 